\title{
REHABILITATION OF MUSLIM REFUGEES IN SARGODHA
}

\author{
Muhammad Rashid \\ Mohamed Ali bin Haniffa
}

\begin{abstract}
The two-nation theory is an ideology of the Indian Muslims to establish their own dominion in Pakistan. The migration of Muslims refugees from India into Pakistan, as a consequence of the partition of India in 1947, ushered a new phase in their lives. The process was not easy from both sides, as the non-Muslims from the newly born Pakistan had to leave their home land and on the other hand Muslims from India had to leave for Pakistan. Sargodha (Shahpur at the time of partition) also received a deluge of refugees. ${ }^{l}$ The process of settlement and rehabilitation of Muslims refugees in this particular region has never been explored. This article highlights the rehabilitation process and its merits and demerits as well as the settlement of migrants in Sargodha City. Using analytical method, this article studies the colonization process as an important part of regional studies.
\end{abstract}

\section{Introduction}

On 23 March 1940, when the Lahore Resolution was passed, it was decided by the Muslims of India that they needed to live in a separate and an essentially Islamic nation. This goal was achieved within seven years on 14 August 1947 after a great struggle and sacrifices. The event brought two things with it: on one hand, it brought the blessing of a separate homeland, the 'land of pure'; it brought a huge flood of looted and penniless Muslim refugees on the other. The partition of the subcontinent left behind a multitude of problems. The problem of refugees' settlement was particularly critical nature as it involved the wishes, sacrifices and emotions of India's Muslims who had nothing but Pakistan. However the Mountbatten's government mismanaged it. ${ }^{2}$ Estimates of the death toll vary from between 200,000 and $1,000,000$. More than ten million Punjabis alone were uprooted at the time of the division. ${ }^{3}$

According to an estimate of the Government of Pakistan, approximately, 6,500,000 refugees came into Pakistan. Of these, 5,200,000 came from East Punjab and the neighboring states while 130,000 from Delhi province. Nearly 5,500,000 Hindus and Sikhs left West Pakistan. It is also claimed that a total of 7.25 million Muslim refugees came from India between 1947 and 1951. Nearly, 5.5 million displaced persons inhabited West Punjab while about 1.5 million moved towards Sindh. Many families from Gujranwala, Gujarat, Sialkot, Jhelum and other parts of the country had already settled here since its creation in 1903. The process of settlement started in 1947 and concluded in 1974. It was a smooth process with no incidence of riots ever recorded.

Sargodha was subject to a process of demographic transition and economic transformation. By the end of March 1948, a total 95,000 refugees settled in the urban area of the Sargodha, while the Non-Muslims who evacuated were 39,000. A total of 85,000 refugees settled in the agricultural rural area and about 56,000 non-Muslim refugees evacuated. In addition, 157,000 refugees settled in the non-agricultural land of rural areas and 54,000 non-Muslim migrated to India. Sargodha received double the number of non-Muslims who evacuated. The Indian Muslims migrants mostly belonged to Ambala, Karnal, Ludhiana and Jullundhur divisions. The process of rehabilitation and resettlement of these Muslim refugees brought about many problems. The occupational structure of the city was completely different from that of the Muslim emigrants. 823 villages were occupied by the Muslims emigrants and they were settled on the lands evacuated by the Hindus and Sikhs. 
Figure 1: Map of United India ${ }^{4}$

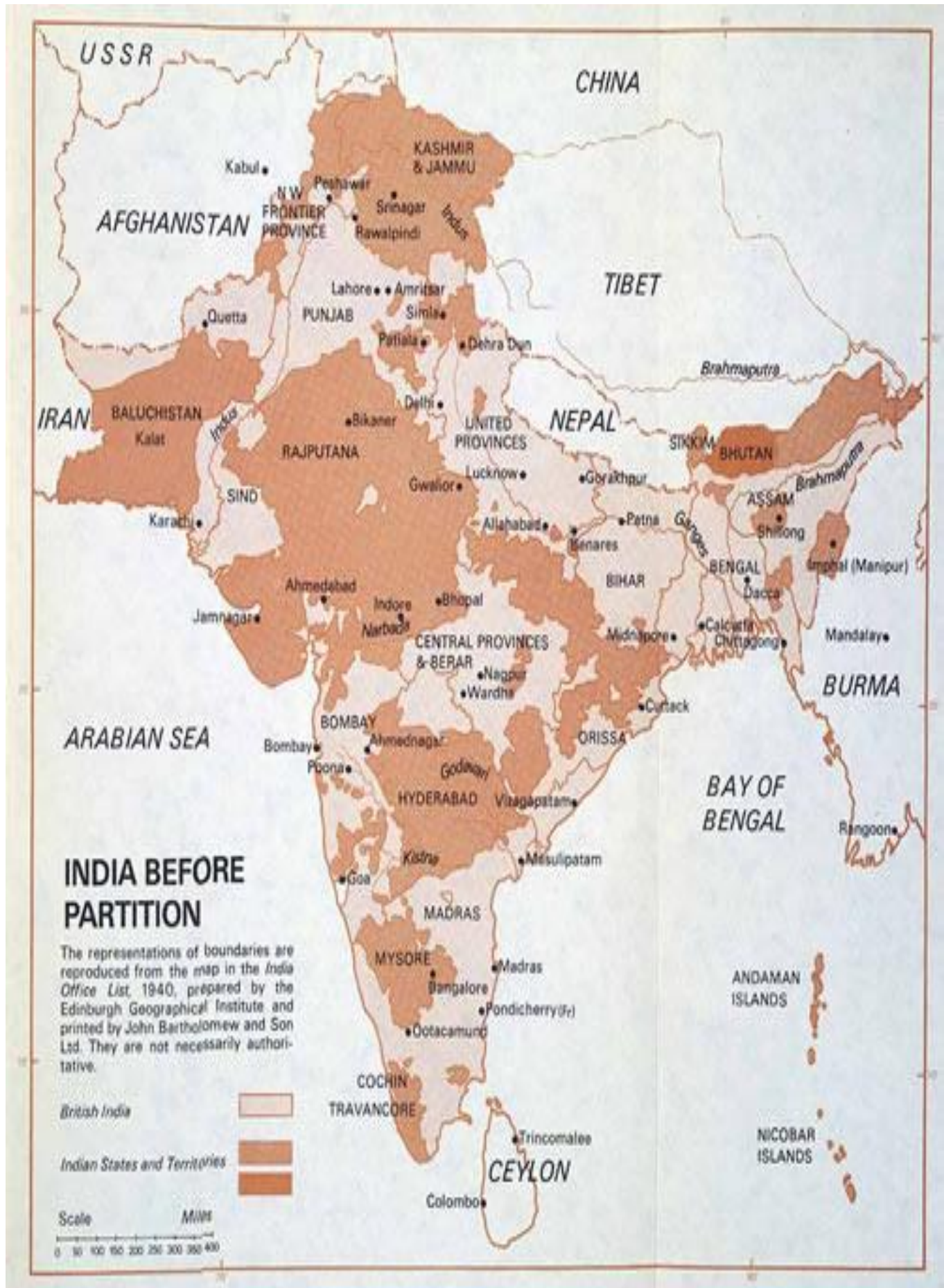

Source: British Library, London. Online sources: 


\section{Findings}

Approximately 6,500,000 refugees migrated into Pakistan. From which 5,200,000 belonged to East Punjab and surroundings states while 130,000 migrated from Delhi province. On the other hand about 5,500,000 non-Muslims left West Pakistan. ${ }^{5}$ It is also said that "a total of 7.25 million Muslim refugees came from India between 1947 and 1951"6 and nearly half a million people died within a few months of partition. ${ }^{7}$ However Sargodha was the only district town in West Punjab where the Hindu and Sikhs could move about freely. ${ }^{8}$ These non-Muslims constituted $14.88 \%$ of the total population. ${ }^{9}$

The Lahore District absorbed about 100,000 refugees. Multan and Montgomery ${ }^{10}$ (now Sahiwal) absorbed 350,000 refugees and the remaining refugees were absorbed by the districts of Sargodha, Sheikhpura, Gujrat, Jhang. Of these it was Sargodha that was heavily populated with Muslim refugees from India. ${ }^{11}$ Muslims refugees belonging to the capitalist class preferred to settle in small cities such as Sargodha, Lyallpur, Jhang and Gujranwala, all which were distant enough from the border area. ${ }^{12}$ About $73 \%$ of the migrants from India landed in West Punjab, making more than 5 million people and constituting $1 / 4^{\text {th }}$ of the population towards the end of the migration process. For instance, Lahore's $43 \%$ population comprised of migrants; the ratio was $65 \%$ for Jhang, $50 \%$ for Gujranwala, $49 \%$ for Multan and $69 \%$ for both Lyallpur (now Faisalabad) and Sargodha. They inhabited West Punjab within a short period of time. ${ }^{13}$

Figure 2: Map of Sargodha District before Partition ${ }^{14}$

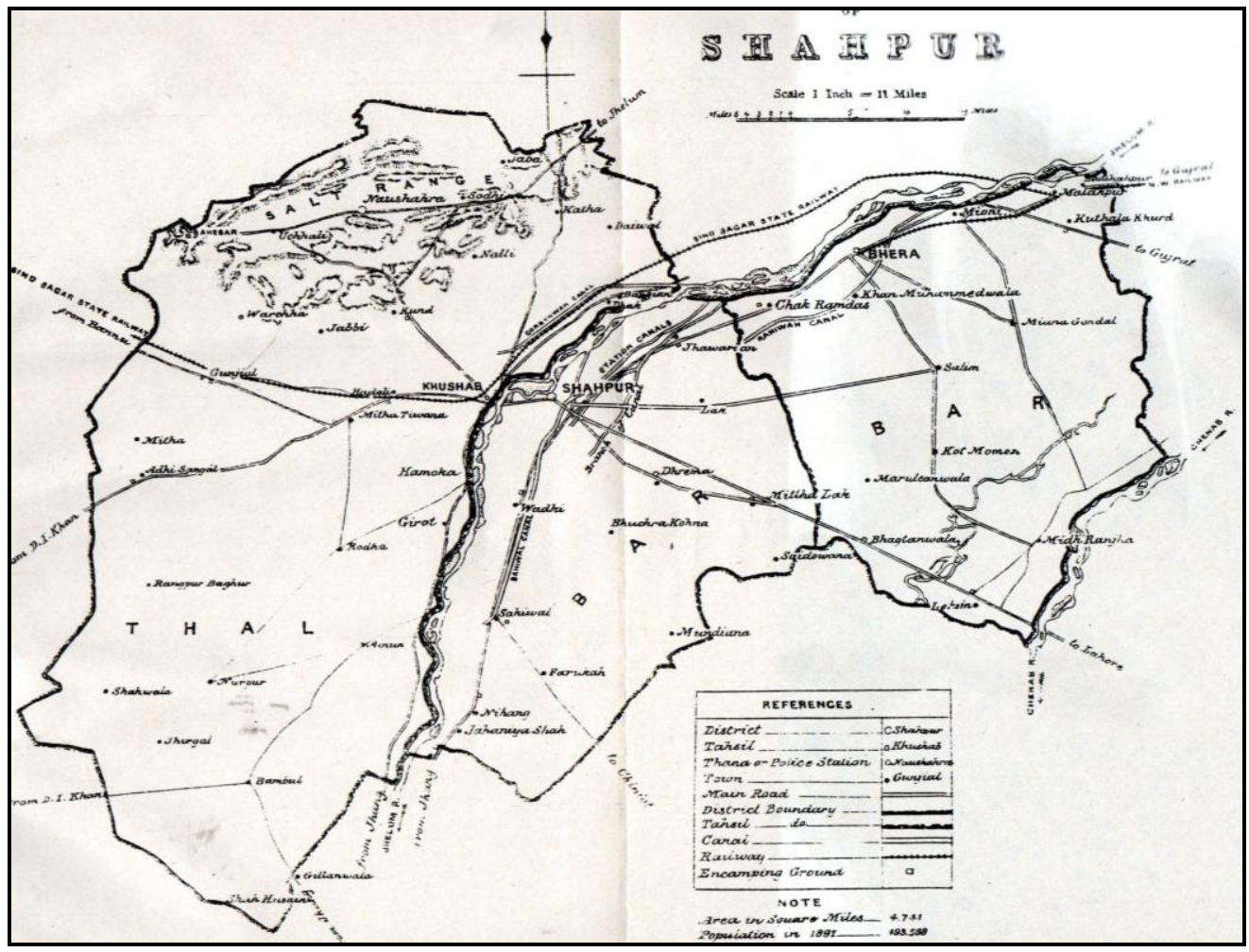

Source: Gazetteer of the Shahpur District 1897

By the end of October 1947, approximately 720,000 Muslim refugees anticipated smooth migration towards West Punjab. Sargodha, Faisalabad and Gujranwala absorbed the majority of the refugees till 1951. About $40 \%$ of refugees settled in Lahore, Multan, Rawalpindi and Sahiwal. ${ }^{15}$ On the other hand, 32,500 in Sargodha, 366,500 in Rawalpindi, 105,000 in Muzaffargarh, 50,000 in Dera Ghazi Khan, 90,000 in Sialkot, 148,000 in Multan, 
32,000 in Gujranwala, 8,500 in Montgomery, 259,600 in Sheikhupura, 167,500 in Lyallpur, 59,000 in Jhang and 8,000 in Lahore. Similarly, non-Muslims also anticipated smooth migration towards East Punjab. ${ }^{16}$

Planes were provided to evacuate the non-Muslims refugees from Sargodha, Lyallpur (Faisalaabad), Sialkot and Dera Ismail Khan Charter. A special organization was also launched and a special officer was appointed to control the "Air Transport for Refugees". ${ }^{17}$ On the whole, West Punjab received 5.5 million refugees and East Punjab received 3.5 million refugees. From the above statements, it can be considered that $1 / 6$ th population of the West Punjab are the 'Muhajirs'. ${ }^{18}$ The following table shows the total figures of refugees who waited for migration (non-Muslims) and those waited for settlement (Muslims) in Sargodha District.

\section{Table 1: Population of District Sargodha Excluding Camps ${ }^{19}$}

\begin{tabular}{|c|c|c|c|c|}
\hline \multicolumn{5}{|c|}{ Total } \\
\hline Hindus \& Sikhs & Refugees & Excess & $\begin{array}{c}\text { Previous } \\
\text { population }\end{array}$ & $\begin{array}{c}\text { Present } \\
\text { population }\end{array}$ \\
\hline 1.64 & 1.83 & +.19 & 10.99 & 11.18 \\
\hline
\end{tabular}

Source: Statistical Data, The Journey to Pakistan: Documentation on Refugees of 1947, National Documentation Centre, Islamabad, 1993, p. 99.

Figure in Lakh.

The following table shows the number of refugees who waited for migration (nonMuslims) and those waited for settlement in the urban areas of Sargodha.

Table 2: Population of District Sargodha in Urban Areas ${ }^{20}$

\begin{tabular}{|c|c|c|c|c|}
\hline \multicolumn{5}{|c|}{ Urban } \\
\hline $\begin{array}{c}\text { Hindus \& Sikhs } \\
\text { (In lakh) }\end{array}$ & $\begin{array}{c}\text { Refugees } \\
\text { (In lakh) }\end{array}$ & $\begin{array}{c}\text { Excess } \\
\text { (In lakh) }\end{array}$ & $\begin{array}{c}\text { Previous } \\
\text { population } \\
\text { (In lakh) }\end{array}$ & $\begin{array}{c}\text { Present population } \\
\text { (In lakh) }\end{array}$ \\
\hline .64 & .84 & .20 & 1.58 & 1.78 \\
\hline
\end{tabular}

Source: Statistical Data, The Journey to Pakistan: Documentation on Refugees of 1947, National Documentation Centre, Islamabad, 1993, p. 99

The following table shows the number of refugees who waited for migration (nonMuslims) and those waited for settlement in the rural areas of Sargodha.

Table 3: Population of District Sargodha in Urban Areas ${ }^{21}$

\begin{tabular}{|c|c|c|c|c|}
\hline \multicolumn{5}{|c|}{ Rural } \\
\hline $\begin{array}{c}\text { Hindus \& Sikhs } \\
\text { (In lakh) }\end{array}$ & $\begin{array}{c}\text { Refugees } \\
\text { (In lakh) }\end{array}$ & $\begin{array}{c}\text { Excess } \\
\text { (In lakh) }\end{array}$ & $\begin{array}{c}\text { Previous } \\
\text { population } \\
\text { (In lakh) }\end{array}$ & $\begin{array}{c}\text { Present population } \\
\text { (In lakh) }\end{array}$ \\
\hline 1.00 & .99 & -.01 & 9.41 & 9.40 \\
\hline
\end{tabular}

Source: Statistical Data, The Journey to Pakistan: Documentation on Refugees of 1947,

National Documentation Centre, Islamabad, 1993, p. 98 
The Government of India and Pakistan cooperated to ensure that these migrants were provided opportunities to contact their family members and tribes in camps and other places so that they could be easily resettled. ${ }^{22}$ In Sargodha, the migrants mostly belonged to the Ludhiana, Jalandhar, Ambala, and District Karnal of Ambala divisions. ${ }^{23}$ On the other hand the non-Muslims of Sargodha and Gujarat were rehabilitated in the Ambala District of East Punjab. ${ }^{24}$

The following tables show the figure (in lakh) of refugees accommodated in camps till the end of February 1947.

\section{Table 4: Refugees in Camps of Sargodha till 07 February $1948^{25}$}

\begin{tabular}{|c|c|c|l|l|l|l|}
\hline & & \multicolumn{3}{|l|}{$\begin{array}{l}\text { No. left camps during } \\
\text { the week }\end{array}$} & $\begin{array}{l}\text { No. in camps at the } \\
\text { end of the week }\end{array}$ \\
\cline { 3 - 7 } $\begin{array}{c}\text { No. of } \\
\text { occupied } \\
\text { camps }\end{array}$ & $\begin{array}{c}\text { No. in camps } \\
\text { till February, } \\
1948\end{array}$ & $\begin{array}{c}\text { No. in } \\
\text { camps at } \\
\text { the start }\end{array}$ & $\begin{array}{l}\text { For } \\
\text { settlement }\end{array}$ & $\begin{array}{l}\text { For other } \\
\text { camps } \\
\text { outside }\end{array}$ & $\begin{array}{l}\text { To be } \\
\text { settled } \\
\text { in }\end{array}$ & $\begin{array}{l}\text { For other } \\
\text { districts }\end{array}$ \\
\cline { 2 - 8 } & (In lakhs) & $\begin{array}{c}\text { (In } \\
\text { lakhs) }\end{array}$ & (In lakhs) & (In lakhs) & $\begin{array}{c}\text { (In } \\
\text { lakhs) }\end{array}$ & $\begin{array}{c}\text { (In } \\
\text { lakhs) }\end{array}$ \\
\hline 1 & .32 & .07 & .07 & -- & .32 & -- \\
\hline
\end{tabular}

Source: Statistical Data, The Journey to Pakistan: Documentation on Refugees of 1947, National Documentation Centre, Islamabad, 1993, p. 115

The following tables shows the figure (in lakh) of refugees accommodated in camps till the end of June 1947.

\section{Table 5: Refugee in Camps of Sargodha till 26.06.1948}

\begin{tabular}{|c|c|c|c|c|c|}
\hline $\begin{array}{c}\text { No. of } \\
\text { occupied } \\
\text { camps }\end{array}$ & $\begin{array}{c}\text { No. in camps } \\
\text { till 10.3.48 }\end{array}$ & $\begin{array}{c}\text { No. in } \\
\text { camps at the } \\
\text { start }\end{array}$ & $\begin{array}{c}\text { No. who arrived } \\
\text { from outside }\end{array}$ & $\begin{array}{c}\text { No. who } \\
\text { left camp }\end{array}$ & $\begin{array}{c}\text { No. in camps } \\
\text { till the end of } \\
\text { the week }\end{array}$ \\
\cline { 2 - 6 } & (In lakhs) & (In lakhs) & (In lakhs) & (In lakhs) & (In lakhs) \\
\hline 1 & .105 & .22 & -- & -- & .22 \\
\hline
\end{tabular}

Source: Statistical Data, The Journey to Pakistan: Documentation on Refugees of 1947, National Documentation Centre, Islamabad, 1993, p. 104

With administrative problems, the problem of refugees' clothing, feeding and the rehabilitation of hastily settled refugees posed greater difficulty for the nascent Government of Pakistan. Quaid-i-Azam Muhammad Ali Jinnah supervised the arrangements. The local population in the districts also provided every facility which they could provide.

To fix quotas of refugees, the Quaid-i-Azam's Relief Fund raised programs especially for the settlement of communication between the federating units. The Quaid himself appealed the peoples in this regard:

The sufferings that have been inflicted on our people in the East Punjab, Delhi and various other parts of the Dominion of India have few 
parallels in their extent. They have confronted Pakistan on the morrow of its birth with problems of gigantic dimension, since we assumed office, my government and I have been spending the best part of our time and energy in dealing with this grave crisis which continues to assume greater proportions as one disaster follows another. ${ }^{27}$

Quaid-i-Azam was well-aware of the problems of the refugees. He made a speech on 11 October 1947 to the Naval, Military and Air Force Officers of Pakistan in Karachi. He stated that:

The disorders in the Punjab have brought in their wake the colossal problem of the rehabilitation of millions of displaced persons. This is going to tax our energies and resources to the utmost extent. It has made the difficulties inherent in the building of a new state; I referred to earlier, manifold. Are we going to allow ourselves to be overwhelmed by the immensity of the task that is confronting us and let our new-born state fonder under the cruel and dastardly blows struck by our enemies? ${ }^{28}$

In the last week of September 1948, when Quaid-i-Azam Muhammad Ali Jinnah was in trance, it was heard from his utterance that:

$$
\begin{aligned}
& \text { Kashmir-- Give them- their rights - decision-ordinance-I will } \\
& \text { complete-quickly-refugee-Give them-every kind of help- } \\
& \text { Pakistan. }{ }^{29}
\end{aligned}
$$

It was decided on 10 October 1947 to register the abandoned properties of refugees in East Pakistan through an organization. Through a press note the Government said that we could not accept any legal responsibility if that person could not be brought under the notice to Government of his evacuee property as soon as possible. And the Act of 1958 was passed for the protection of Evacuee property for the displaced persons (compensation and rehabilitation) ${ }^{30}$ For the protection of these properties whether moveable or immovable was later called "Evacuee Property", known in (protection of Evacuee Property) ordinance of 1948 (XVIII of 1948) enforced from October 18, 1948 and the same law was repealed by the Pakistan (Administrations of Evacuees Property) Ordinance of 1949 (XV of 1949).

For the allotment of evacuee, the 'Land Settlement Act 1958'31 was promulgated and for the allotment of evacuee urban properties to displaced persons a "Compensation and Rehabilitating Act 1958" was passed. For the rehabilitation of refugees in Sargodha the same laws and methods were projected. The emigrants of Sargodha District established their business after the peaceful evacuation of Hindus and Sikh in Sargodha. The 'do hunter', a big soap-making factory in Sargodha, for example, was allotted to a refugee. Its name was subsequently changed to "Qanchi Marka". Shops full of necessary items left by Hindus and Sikhs were given to the Muhajirs. ${ }^{32}$

The following statement shows the rehabilitation made in the district of Sargodha till the week ending 13 March 1948. 
Table 6: Refugees' settlement in Sargodha till March, $1948^{33}$

\begin{tabular}{|c|c|c|c|c|}
\hline \multicolumn{3}{|c|}{$\begin{array}{l}\text { No. of refugees resettled or absorbed by the } \\
\text { end of the week }\end{array}$} & \multirow{3}{*}{$\begin{array}{l}\text { No. of villages } \\
\text { evacuated by non- } \\
\text { Muslims }\end{array}$} & \multirow{3}{*}{$\begin{array}{l}\text { No. of villages } \\
\text { occupied by refugees }\end{array}$} \\
\hline \multirow{2}{*}{ Towns } & & Rural & & \\
\hline & Agricultural & Non-Agricultural & & \\
\hline 95000 & 85000 & 157000 & 823 & 823 \\
\hline
\end{tabular}

Source: Statistical Data, The Journey to Pakistan: Documentation on Refugees of 1947, National Documentation Centre, Islamabad, 1993, p. 111.

From the above figure, refugees settled on 823 villages evacuated by the non-Muslims following the settlement policy. A total of 95,000 and 85,000 refugees settled in the urban and rural areas of the Sargodha respectively and 157,000 refugees settled in the rural area on non-agricultural lands.

Table 7: Non-Muslims evacuation in Sargodha ${ }^{34}$

\begin{tabular}{|c|c|c|}
\hline \multirow{2}{*}{ No. of Non-Muslim evacuees from (In Lakhs) } \\
\hline \multirow{2}{*}{ Towns } & Agricultural & Rural \\
\cline { 2 - 3 } & .56 & .54 \\
\hline
\end{tabular}

Source: Statistical Data, The Journey to Pakistan: Documentation on Refugees of 1947, National Documentation Centre, Islamabad, 1993, p. 111.

From the above figures the non-Muslims who left for East Punjab were 39,000, 56,000 and 54,000, from the town, agricultural rural areas and non-agricultural rural areas respectively.

Table 8: Difference of population after settlement of refugee in Sargodha ${ }^{35}$

\begin{tabular}{|c|c|c|c|}
\hline \multirow{2}{*}{ Difference } \\
\hline \multirow{2}{*}{ Communities } & \multirow{2}{*}{ Towns } & Agricultural & Non Agricultural \\
\cline { 3 - 4 } & & $(85000)$ & $(157000)$ \\
\hline Muslims & $(95000)$ & $(56000)$ & $(54000)$ \\
\hline Non-Muslims & $(39000)$ & $\mathbf{2 9 0 0 0}$ & $\mathbf{1 0 3 0 0 0}$ \\
\hline Total & $\mathbf{5 6 0 0 0}$ & Rural & \\
\hline
\end{tabular}

Source: Statistical Data, The Journey to Pakistan: Documentation on Refugees of 1947, National Documentation Centre, Islamabad, 1993, p. 111.

From the above figures the difference in population between the Muslims and nonMuslims increased to 56,000, 29,000 and 103,000 in the town, agricultural rural areas and non-agricultural rural areas respectively. It has been claimed that the Muslims had left 3.4 million acres in East Pakistan while the non-Muslims had left 6.6 million acres in West Punjab. On the other hand the Punjab Board of Economic Enquiry in West Punjab (Pakistan) claimed that Muslims left 7.114 million acres of land and the non-Muslims left 4.836 million acres from their place of origin. Migration also increased the population of the new state by about $1,000,000 .{ }^{36}$ 
The following table shows the census record of Sargodha district and the figures obtained from the census of 1941, 1951 and 1961.

Table 9: Census report of Sargodha district ${ }^{37}$

\begin{tabular}{|c|c|c|c|c|c|}
\hline \multicolumn{3}{|c|}{ Population } & \multicolumn{3}{c|}{ P.C Increase } \\
\hline 1941 & 1951 & 1961 & $1941-51$ & $1951-61$ & $1941-61$ \\
\hline 36,420 & 78,447 & $1,29,291$ & 115.4 & 64.8 & 255.0 \\
\hline
\end{tabular}

Source: Census of Pakistan Population 1961.

In the above figure, it is reflected from the censuses of 1941 and 1951 that the population of Sargodha city was 36,420 and which gradually increased until the partition of the Punjab in 1947. This also shows that excess numbers of refugee were settled in the district Sargodha. Therefore, their rehabilitation process was an uphill task. The process of settlement and rehabilitation of refugee could have been completed within 2 or 3 years. ${ }^{38}$

Sargodha was ruled by landlords. When the non-Muslims evacuated Sargodha the authorities were pre-occupied with the evacuated lands, leading to disorders in the settlement process. The cases are still pending in settlement branch of Sargodha. Illegal allotments were also made on different grounds. As Alhaaj Hafiz Ghulam Hassan, Deputy Commissioner of Sargodha was appointed, Magistrate Jafri Sahib, an allotment officer who was among the refugees, revealed that he took bribes for the allotment. An evacuated building namely Sheesha Ram Bagh was to be made "Widow House" in which the newly coming widows and orphans were considered to stay. However Deputy Commissioner Alhaaj Hafiz Ghulam Hassan allotted it to the relatives of Malik Fateh Muhammad Tiwana. ${ }^{39}$

The Deputy Commissioner also took back buses and trucks of Hindus and Sikhs by issuing the permit and evacuated factories were unlawfully named to the people. Mian Mumtaz Dultana, ${ }^{40}$ a prominent figure in the government, illegally allotted flour mill in Sargodha to his brother-in-law. ${ }^{41}$ Advocate Chaudhry Faiz Ahmad also allotted the land about eight marabhas in Sargodha's Sahiwal Tehsil, which was very loyal to corrupt government at that time.

The term Jarlu was introduced for the first time for this corrupt or illegal allotment. And in the end, the death of Quaid-i-Azam Muhammad Ali Jinnah was a psychological blow for the refugees. In Sargodha, after the news of Quaid-i-Azam's passing was announced, a migrated old lady said: "What will be done with us now". ${ }^{42}$ 
Figure 3: Map of Sargodha District after Partition 1947

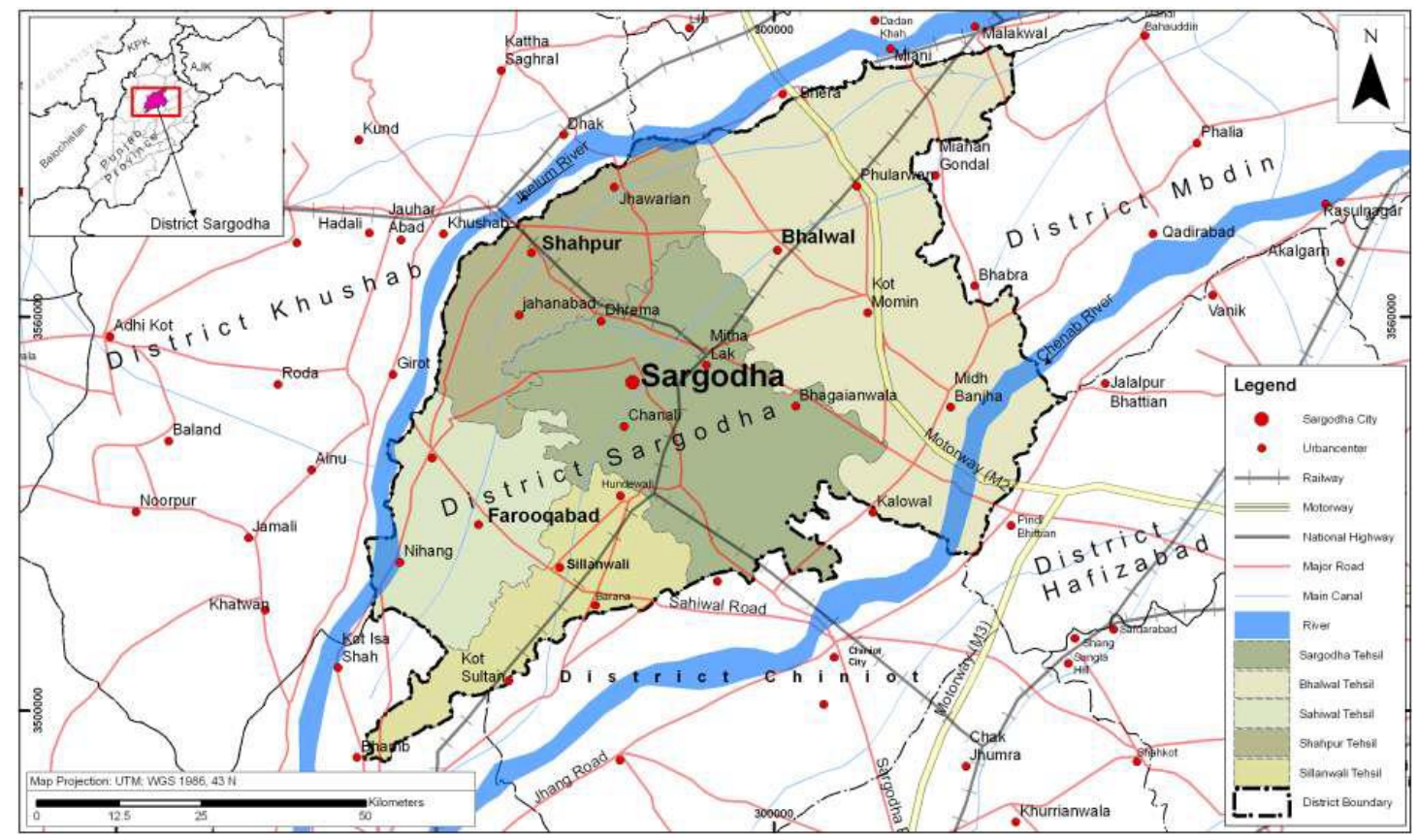

Source: Department of Planning and Developing, Punjab City Improvement plan, Sargodha City Profile. p.15

\section{Concluding Remarks}

The partition of the subcontinent did not happen suddenly. There were many reasons behind the partition of subcontinent. Both the Muslims and Hindus remained obdurate to their respective Muslim and Hindu nationalist sentiments. The main reason is that both these communities belonged to different cultures. Their lifestyles ranging from food, language, marriage laws, education, households and especially religious beliefs fundamentally different from each other. On 14 August 1947, Pakistan - the land of pure - appeared on the world map. This resulted in a process of migration from both sides as the non-Muslims migrated towards East Punjab (India) while the Muslims migrated towards West Punjab (Pakistan).

The penniless Muslims refugees settled in Sargodha through the settlement policy or with their relatives already settled in the city. The entirely different environment of Sargodha District for the newly arriving refugees brought more problems. Biases that existed in the psyches of local people and the Muhajirs are less obvious in the urban zone than the rural areas of the Sargodha. The reason is that the proficiency level in urban region was considerably higher. Urban lifestyle was also considerably busier compared to the dormant rustic routines in the rural areas. In short, this new phase in Sargodha represented a case of social solidarity. 


\section{Notes}

${ }^{1}$ Shahpur takes its name from a small town near the Rive Jhelum, celebrated for its shrine of Shah Shams. After the floods in Shahpur and due to some other problems, the district headquarter was transferred from Shahpur to Sargodha in 1913 but it continued to be called Shahpur district till 1960. Shahpur District, which included the modern city of Sargodha, was very much a part of the western overwhelming Muslim-majority areas of the Rawalpindi division. Ahmed, Ishtiaq, The Punjab Bloodied, Partitioned and Cleansed: Unravelling the 1947 Tragedy through Secret British Reports and First-Person Accounts, Oxford: University Press, 2012, pp. 375. See also Punjab District Gazetteers Volume XXX A, Shahpur District, K 21 (a) XXII, Punjab Archive, Lahore. p. 1.

${ }^{2}$ Rear Admiral Lord Louis Mountbatten, a cousin of King George VI, was serving as Supreme Allied Commander of South East Asia before sending to India replacing Wavell as the last GovernorGeneral of United India. His appointment was largely motivated by the Congress influence. He arrived in India on 22 March 1947, to take over charge as the thirty fourth and the last Viceroy of India. Lord Mountbatten's part in the capacity of the last Viceroy of United India gets the significant piece of consideration as he was the Crown representative in India, as well as the man on the ground taking real choices. His association with other political pioneers and his treatment of the circumstance was critical in the mutually tense and unpredictable Indian circumstance. He gave just only 72 days for the partition of India which is quite difficult task while on the other hand it took 2 or 3 years to separate Sindh from Mumbai and also Burma from India. His silence on certain issues of outstanding importance, such as involvement in the working of the boundary commission, seems quite incomprehensible. In Chaudhri Muhammad Ali's opinion, no move was made against the Sikh leaders in the Punjab who, to his specific information, were arranging a genocide campaign. Uprooting of more than ten million people death of two million people including children, rape of nearly 100,000 women, the situation of Punjab in the midst of widespread intimidation, terror, violence, abduction, rape, murder, the issue of State of Hyderabad, Junagarh and still the main bone of connection between India and Pakistan on the issue of Kashmir was surely the Mountbatten's government mismanaged. See Rabia Umar Ali, Partition of the Indian Subcontinent: Planning and Implementation, Dissertation, Quaid-i-Azam University, Islamabad, 2009, Christiane Hartnack, "Roots and Routes: The Partition of British India in Indian Social Memories", Journal of Historical Sociology, 2012, pp. 244, Urvashi Butalia, The Other Side of Silence: Voices from the Partition of India, New Delhi: Penguin India. 1998, pp. 1-6.

${ }^{3}$ Ian Talbot, "Pakistan and Sikh Nationalism: State Policy and Private Perceptions", Sikh Formations, 2010, p. 65, Ian Talbot, "Literature and the Human Drama of the 1947 Partition", South Asia: Journal of South Asian Studies 18.s1, 1995, pp. 37 and 47, Bose, Sarmila, "The Question of Genocide and the Quest for Justice in the 1971 War", Journal of Genocide Research, 2011, pp. 404, Tony Ballantyne, "History, Memory and the Nation: Remembering Partition", New Zealand Journal of Asian Studies, 2003, p. 195.

${ }^{4}$ http://www.bl.uk/reshelp/findhelpregion/asia/india/indianindependence/map1/index.html. Retrieved on 15 February 2018.

${ }^{5}$ F. A. Dar, Communal Riots in the Punjab 1947, Islamabad: NIHCR, 2003, p. 173.

${ }^{6}$ I. T. Thandi, People on the Move: Punabi Colonia, adn Post-Colonial Migration, Karachi: Oxford University Press, 2004, p. 64.

${ }^{7}$ A. Saleem, Partition, Violence and Migration: The case of Miana Gondal, working paper series \# 85. Islamabad: SDPI, 2003, p. 85.

${ }^{8}$ R. Symonds, In the Margins of Independence: A Relief Worker in India and Pakistan (1942-1949), Karachi: Oxford University Press, 2001, p. 51.

${ }^{9}$ A. S. Pasha, 72 din: 4 june 1947 say 14 August 1947 (in urdu), Lahore: Sang-e- Meel publication. p. 62.

${ }^{10}$ The city was given the name of Montgomery in 1865 because Sir Robert Montgomery, the then Lieutenant-Governor of Punjab. It is about 180 kilometer away from Lahore, the main city of Punjab. In 1967, its name was reinstated as Sahiwal after the Sahi caste who are the native inhabitants of this area. 
${ }^{11}$ Ishtiaq Ahmed, The Punjab Bloodied, Partitioned and Cleansed: Unravelling the 1947 Tragedy through Secret British Reports and First-Person Accounts, Oxford: Oxford University Press, 2012, p. 315. See also Advocate, Muhammad Hayat, Tehrik-e-Pakistan or Sargodha ki Yadain (in Urdu), Sargodha: Khalid Printing Press, 1984, p. 115.

${ }_{12}$ I. Chattha, Partition and Locality: Violence, Migration, and Development in Gujranwala and Sialkot, 1947-1961. Karachi: Oxford University Press, 2011, p. 97.

${ }^{13}$ M. Waseem, Migration and Assimilation: A Comparative Study of Pakistani Punjab, Region and Partition . Karachi: Oxford University Press, 1990, p. 217.

${ }^{14}$ Gazetteer of the Shahpur District, 1897.

${ }^{15}$ M. Waseem, Politics and the State in Pakistan. Islamabad: NIHCR, 2007, p. 108.

${ }^{16}$ The Hindustan Times, 11 October 1947, p. 3.

${ }^{17}$ K. Kaur, Riots, Refugee adn Rehabilitation: A Case Study of Punjab 1946-56, Phd Thesis, Patiala: Punjabi University, 2010, p. 97.

${ }^{18}$ K. B. Sayeed, Pakistan the Formative Phase 1857-1948, Karachi: Oxford University Press, 1998, p. 265.

19 Statistical Data, The Journey to Pakistan: Documentation on Refugees of 1947, National Documentation Centre, Islamabad, 1993, p. 99.

${ }^{20}$ Ibid.

${ }^{21}$ Ibid., p. 98.

${ }^{22}$ Ian Talbot and Shinder Thandi, People on the Move: Punjabi Colonial and Post-Colonial Migration, Oxford University Press, 2004, p. 72.

${ }^{23}$ S. A. Rasul, The History of Sargodha, Sargodha: University of Sargodha, 2006, p. 238.

${ }^{24}$ S.A. Rasul, Refugee and Rehabilitation: A Case Study of Punjab 1946-56, p. 97.

25 Statistical Data, the Journey to Pakistan: Documentation on Refugees of 1947, National Documentation Centre, Islamabad, 1993, p. 115.

${ }^{26}$ Ibid, pp. 104.

${ }^{27}$ Quaid-i-Azam Mohammad Ali Jinnah Speeches as Governor General of Pakistan 1947-1948, 2004, p. 115.

${ }^{28}$ Ibid.

${ }^{29}$ Z. Chaudhry, Jinnah Liaqat Tazad \& Punjabi Muhajir Tazad (in Urdu), Lahore: Shirkat Printing Press, 2013, p. 326.

${ }^{30}$ M. Latif, The Displaced Person (Compesation \& Rehabiliation) Act 1958, Lahore: Imran Law Book house, 2013.

${ }^{31}$ Ibid.

${ }^{32}$ Interview with Sahibzada Abdul Rasul, May 302014.

33 Statistical Data, the Journey to Pakistan: Documentation on Refugees of 1947, National Documentation Centre, Islamabad, 1993, p. 111.

${ }^{34}$ Ibid.

${ }^{35}$ Ibid.

${ }^{36}$ F. A. Dar, Communal Riots in the Punjab 1947, Islamabad: NIHCR, 2003, p. 164.

${ }^{37}$ Census of Pakistan Population 1961.

${ }^{38}$ Sibt-e-Hassan, Pakistan k Tahzibi wa Siyasi Misayal, Karachi: Maktab-e-Danyal, 2002, p. 201.

39 Advocate, Muhammad Hayat, Tehrik-e-Pakistan or Sargodha ki Yadain (in Urdu), Sargodha: Khalid Printing Press, 1984, p. 77.

${ }^{40}$ Mian Mumtaz Daultana, the son of Nawab Ahmad Yar Khan Daultana, a renowned Unionist and political figure of Punjab joined Muslim League in 1942 and worked during the freedom movement under the leadership of Quaid-i-Azam. He was also the member of Direct Action Committee. In 1946, Mumtaz Daultana hold the chair of Chief Minister of Punjab from April 15, 1951 to April 03, 1953.

${ }^{41}$ Civil and Military Gazette, 17 July 1950, p.3.

${ }^{42}$ Advocate, Muhammad Hayat, Tehrik-e-Pakistan or Sargodha ki Yadain (in Urdu), Sargodha: Khalid Printing Press, 1984, p. 97. 
Sejarah, No. 27, No. 1, 2018, hlm. 43-54. 